\title{
HNF1A Gene Mutation
}

National Cancer Institute

\section{Source}

National Cancer Institute. HNF1A Gene Mutation. NCI Thesaurus. Code C96763.

A molecular genetic abnormality indicating the presence of inactivating mutation of the HNF1A (hepatocyte nuclear factor 1-alpha) gene. 